\section{Dr Anne Szarewski}

\section{September 1959-24 August 2013}

The October 2013 issue of this Journal conveyed the news of the death of our Editor-in-Chief in the form of an immediate but warm and personal tribute by her close friend, Diana Mansour. We now publish a selection of the commissioned and spontaneous tributes to Anne that the Journal has received. These will, we hope, stand as a lasting memorial to our friend and colleague. With these appreciations of Anne, we also extend our commiserations for his sudden and completely unexpected loss to her husband, the journalist Lester Venter.

Anne became Editor-in-Chief of the Journal of Family Planning and Reproductive Health Care in 2003. Her professional life, which combined running frontline sexual and reproductive health clinics at the Margaret Pyke Centre in London with innovative research into the prevention of cervical cancer with Cancer Research UK, made her the ideal person for this role. Her international reputation led to her being called upon to lecture widely. This gave her great opportunities for networking, resulting in her commissioning Journal articles from numerous British and world authorities and in the enhancement of our international Advisory Board. The quarterly meetings of the Journal's Editorial Board were conducted by Anne with tact and insight, so that we all felt part of the Journal family and deeply involved in a project that saw a remarkable increase in the Journal's quality and international recognition during her editorship. One of our Associate Editors summed up Anne's role so perfectly: she was our colleague, mentor and friend. We will all treasure fond memories of her.

\section{David Horwell}

Acting Editor-in-Chief, Journal of Family Planning and Reproductive Health Care

\section{THE JOURNAL}

I had the privilege and pleasure of working alongside Anne on the Journal for 10 years and very early on recognised the essential skills she brought to the role of Editor-in-Chief: her impressive knowledge of sexual and reproductive health care; her wide range of contacts, always knowing the appropriate person to approach, whether as a contributor or peer reviewer; her incisive and invariably correct decision-making; and her talent for and enjoyment of the editing and proofreading processes.

Yet Anne would have been the first to admit to being a dinosaur when it came to new technology. Over the years she and I familiarised ourselves with the idiosyncrasies of online manuscript tracking systems, and somewhat reluctantly embraced the 'Brave New World' of social media, grappling with the (then) new and unfamiliar phenomena of Facebook, Twitter, RSS feeds and blogs.

Anne's keen interest in - some might say obsession with - improving the Journal's Impact Factor was well known, and during her tenure this measure of a journal's scientific importance increased year on year, an achievement that made her particularly proud. It was of vital importance to Anne that the Journal's international visibility and influence should grow, and under her editorship it developed from being a primarily UK-based society journal into a truly international publication that is highly respected in its field.

Anne worked closely with the Journal's international Editorial Advisory Board and UK-based Editorial Board, chairing inspirational and productive quarterly editorial meetings of the latter, at which participants were encouraged to voice their opinions and to take an active role in the Journal's ongoing development.

Anne quite simply loved being Editor-in-Chief, and even after 10 years she had no desire to relinquish this role. With her untimely death the Journal lost a passionate advocate and a truly inspirational editor. Her act will without doubt be a hard one to follow.

\section{Janie Foote}

Editorial Manager, Journal of Family Planning and Reproductive Health Care

\section{THE MARGARET PYKE CENTRE}

My first memory of Anne is a TV interview in the early 1980 s, at the time of a 'pill scare' concerning (I think) the pill and breast cancer risk. Recently out of medical school, it was already obvious that she was poised, articulate, informed, and exceptionally good at communicating with lay people.

At the Margaret Pyke Centre right up to her so untimely death, Anne continued doing regular clinical and research sessions. She was highly respected as an adviser, succeeding me in that role for the British National Formulary, and an ambassador in all aspects of women's

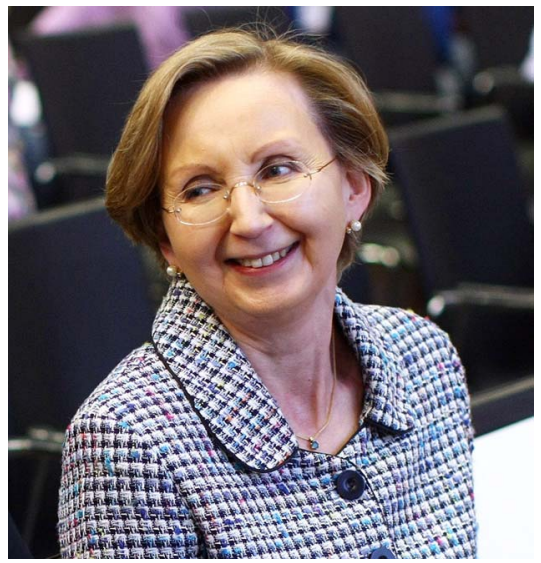

health. We jointly authored many letters, review articles and research papers and a book translated into six languages (Contraception - A Users' Handbook, OUP). But I would give her all the credit for the innovative hypotheses that she managed to confirm. As one example, in a unique intervention trial that led to her $\mathrm{PhD}$, she managed to persuade enough volunteers to cease smoking (confirmed by cotinine levels) to establish convincingly a diminution in the size of mild CIN lesions compared with ongoing smokers, along with confirmatory biological effects on cervical Langerhans cells and lymphocytes. Using her skill in colposcopy and working with Centre volunteers she did some of the earliest work on human papillomavirus (HPV) and cervical neoplasia and demonstrated the best of four samplers for cervical screening.

Anne's lectures attracted large audiences, drawn by their excellent content delivered with humour and a wry tilt at intolerance and institutional bureaucracy. Always immaculately turned out and elegant, she was never 'wallpaper' and had strong and sometimes dogmatic views about most things, medical or not. We agreed to differ, always amicably, on some matters such as Depo-Provera ${ }^{\circledR}$ and bone density, and when co-authoring chapters on the infamous 1995 'pill scare'. Any apparent intransigence was driven by her central concern for the women and colleagues she worked with. No-one was unimportant and she was never 'too busy' to provide a prompt answer to a clinical query or an e-mail from a patient.

\section{John Guillebaud}

Emeritus Professor of Family Planning and Reproductive Health, University College, London, UK; Medical Director, Margaret Pyke Centre for Study and Training in Family Planning, London, UK, 1978-2003 


\section{SUPPORT FOR NURSES}

Anne believed in the caring nature and skills of nurses. Working alongside her was stimulating, pleasurable and fun.

From the mid-1980s she gave numerous lectures especially to postgraduate nurses. She particularly went out of her way, with a wicked sense of humour and simple practical hints, to teach the skills of smear taking. I recall her saying: "The quality of the sample for the laboratory is in the experience of the smear-taker rather than the type of spatula used". At such times Anne demonstrated three different types of spatula, one being the Cytobrush $^{\odot}$, which we nicknamed the mini loo brush or mascara brush. All the students were given samples: I wonder what happened to them all? One of her early publications was A Woman's Guide to the Cervical Smear Test, which the students were encouraged to read.

From the mid-1990s onwards I was fortunate to attend various lectures of Anne's at conferences of the European Society of Contraception and Reproductive Health. They were always thought-provoking, but would also have the large audiences in stitches of laughter.

Anne always encouraged, listened to, and supported nurses not only in their clinical roles, but also academically, and when faced with challenging committee sessions.

\section{Maddy Ward}

Retired Clinical Nurse Specialist, Contraception and Reproductive Health Care;

Former Nurse Tutor, Margaret Pyke Centre, London, UK

\section{CAREER AND RESEARCH}

Anne qualified MBBS at the Middlesex Hospital in 1982 and began her career as a doctor at the Whittington and Royal Free Hospitals. She then moved into family planning and sexual health and joined the staff at the Margaret Pyke Centre in 1986. She trained in colposcopy at the Royal Northern Hospital under one of its early practitioners and enthusiasts, Mr Albert Singer. Here she developed her interest in cervical cancer detection and screening.

Her academic career began at the Mathematics, Statistics and Epidemiology Laboratory of the Imperial Cancer Research Fund (later Cancer Research UK), and continued after 2002 in the Centre for Cancer Prevention at the Wolfson Institute of Preventive Medicine, Queen Mary University of London. Whilst undertaking her $\mathrm{PhD}$ on
'The effect of cessation of smoking on cervical lesion size and immune cell parameters' Anne continued to work on other research projects. She was the clinical lead on the trial that resulted in the publication of a paper showing that testing for the presence of HPV DNA in cells taken during cervical screening would pick up cases of pre-cancer that were missed by conventional cytology testing. This was a notable development in the field of HPV testing, now routinely used in cervical screening programmes throughout the world. Anne followed this with a larger multi-centre HPV screening trial - the HART study. Published in 2003, evidence from this played a role in the decision of the International Agency for Research on Cancer (IARC) to recommend that HPV testing could be used in primary cervical screening. Anne was also one of the first to study the possibility of HPV testing on self-collected vaginal samples; an approach to improve screening uptake both in low-resource settings and for those women who find clinician sampling difficult. As chief investigator, principal investigator and author on key HPV vaccine clinical trials, Anne was a keen advocate of HPV vaccination.

Anne's dual clinical interests in contraception and cervical cancer prevention continued when Anne became a leading expert on Depo-Provera and third-generation combined oral contraceptives.

To many, Anne's genius was in communicating complex medical issues with passion and conviction to a wide audience. Whether in her books, lecturing to medical students or writing for national newspapers or magazines, Anne would convey her message with scholarship and wit. Her much loved cat, Bertie, often featured in her lectures, and she was determined that he would have been first in line for a vaccine for feline papillomavirus! Anne never failed to be outspoken in support of those issues about which she felt strongly such as third-generation combined oral contraceptives, and HPV vaccination for boys.

Anne was a caring clinician who was unfailingly loyal to her patients and colleagues. She was something of an enigma - she professed to have no understanding of statistics but chose to work in analytic epidemiology. She thought that most mathematicians were somewhere on the autistic spectrum, but spent much of her career working closely with them and trying to 'speak' their language.
Anne's lively, upbeat personality, kindness and conscientious attention to detail in the increasingly bureaucratic fields of medicine and research, as well as her insistence on putting women's needs first, will be greatly missed.

\section{Jack Cuzick}

John Snow Professor of Epidemiology and Director of the Wolfson Institute of Preventive Medicine, London, UK

Director of the Centre for Cancer Prevention, London, UK

\section{Peter Sasien}

Professor of Biostatistics \& Cancer Epidemiology and Deputy Director of the Centre for Cancer Prevention, Wolfson Institute of Preventive Medicine, London, UK

\section{Louise Cadman}

Research Nurse Consultant, Centre for Cancer Prevention, Wolfson Institute of Preventive Medicine, London, UK

\section{RESEARCH FOR WOMEN'S HEALTH}

Anne was a wonderful advocate for the health and welfare of women, and with her death women have lost a very good friend. She was a distinguished clinical researcher who was a key figure in the pivotal studies that showed that HPV testing - objective molecular testing was more sensitive in detecting highgrade pre-cancers of the cervix than conventional cervical cytology, and she was one of the principal investigators in the clinical trials of the bivalent HPV vaccine, Cervarix ${ }^{\circledR}$. Anne was a natural communicator, always pitching her message perfectly to the audience or individual. This attribute was central to her clinical research and her advocacy for women's health where her rapport and empathy enabled recruitment and retention of women in clinical trials, whether for HPV testing or vaccination.

Anne's contribution to the success of the HPV vaccine in the UK was considerable. She was a tireless educator of the doctors, nurses and other health professionals engaged in the delivery of the vaccine in both the schools programme and catch-up in the community. She had excellent media contacts and could inform journalists in a factual and understandable way about the disease, the vaccine and its positive health benefits. Her participation in education programmes globally for gynaecologists and health workers married with her efforts in the UK in increasing understanding of $\mathrm{HPV}$ and its role in cervical disease. Anne was a great 
colleague, organised, good humoured and always meticulously prepared for the task in hand. Those of us who worked with her will miss her greatly.

\section{Margaret Stanley OBE}

Professor of Epithelial Biology, Department of Pathology, University of Cambridge, Cambridge, UK

\section{A LONG FRIENDSHIP}

I met Anne in 1988. She was working as a doctor at the Margaret Pyke Centre in Soho and I was a medical representative, later taking on a national and international role around pharmaceutical professional relations. Anne was always supportive and a wonderful friend and teacher, helping me to understand the science and the wider issues around sexual and reproductive health care. Our friendship developed through our mutual interest in restaurants, the stage and the screen. I accompanied Anne some 18 years ago to the depths of south London to find Bertie - her darling cat to whom I was 'godmother'.

We shared many wonderful experiences travelling the length and breadth of the UK and indeed to many places around the world, embracing knowledge both in medicine and the arts. The 'Theatre Group' was founded, a bunch of people from disparate backgrounds and nationalities, where Anne took control in organising our regular Saturday afternoon outings, of course including lunch! The group will continue, although probably with less efficiency.

In 2005 Anne was instrumental in my 'coming in from the dark side' to work at the Faculty of Sexual \& Reproductive Healthcare. I have never been happier in my work - thank you Anne.

\section{Diana Halfnight}

Head of Meetings and External Communications, Faculty of Sexual \& Reproductive Healthcare, London, UK

\section{'BROKEN THREADS...'}

We never met and never even spoke to each other, yet recently we were in contact when preparing the simultaneous publication of a position statement authored by some 26 clinicians, concerning the risk of thromboembolism associated with the use of combined hormonal contraceptives. The paper was to appear both in this Journal and in the European Journal of Contraception and Reproductive Health Care. I was impressed by the wisdom of Anne's suggestions and the stimulating effect of her no-nonsense approach, not least with regard to getting the job done well and quickly. Later in 2013 we were in touch again when asked by Khalid Khan, Editor-in-Chief of BJOG, to endorse, on behalf of our journals, a proposal to encourage publication of key outcomes in a standardised fashion, to permit comparison across research studies. Being very aware of the need for this, we were among the first to support this initiative. In the search for an acronym, Professor Khan had suggested 'CROW'. A lively debate followed between those in favour and those against. I belonged to the former and informed all colleagues that I loved birds and that I had had a redtailed grey parrot, which I fed with goodies purchased from Fauchon, the Paris culinary emporium. In no time Anne replied that, knowing that, she would never again dare to feed the sparrows with crumbs of ordinary bread.

In August, I went on holiday. Upon my return I found messages in my mailbox informing me of Anne's sudden demise. I was shattered. The thread of a burgeoning friendship between us, and that of a closer collaboration between our journals that she and I were spinning, had broken. Why should someone depart who was so young, so talented, multilingual, with a taste for art and good music, and a fine sense of humour? Fortuna, the goddess of chance, at times does very silly things. This time she must have gone mad.

\section{Jean-Jacques Amy}

Emeritus Professor of Obstetrics and Gynaecology, Vrije Universiteit, Brussels, Belgium;

Editor-in-Chief, European Journal of Contraception and Reproductive Health Care

\section{TEACHER, COLLEAGUE, FRIEND}

I was devastated to hear the news about Anne's premature passing away. She was enormously influential in many of our lives, both as a dear friend and as a respected colleague.

I first met Anne at the Margaret Pyke Centre during my family planning training more than 20 years ago. My respect for her grew very rapidly; her inspirational teaching was one of the main encouragements to continue my professional education and research within the field of reproductive medicine.

It was an honour to be invited by Anne to join the Editorial Advisory Board of this Journal. Her infectious enthusiasm and commitment made it a pleasure, not a chore, to provide her with regular contributions to the Journal. As a Co-Editor-in-Chief myself, I was not surprised to see the Impact Factor of this Journal rise almost exponentially under Anne's expert stewardship, establishing it globally as one of the most respected gynaecological journals. I have no doubt that David Horwell, Janie Foote and the rest of the team will ably maintain the high standards that Anne set.

Anne and I shared the platform at many conferences both as speakers and chairs, presenting both our own and industry-sponsored research. I thoroughly enjoyed working with her; she knew how to strike the perfect balance between academia, professional integrity and social networking.

It is well recognised that Anne was a great researcher and educator in the fields of cervical pre-cancer and family planning, but most of all, she was a trusted friend and colleague to many. She could always be relied upon to provide support when needed. Having contributed so much during her life, her spirit will live on eternally in our memories.

\section{Nick Panay}

Immediate Past Chairman, British Menopause Society; Co-Editor-in-Chief, Climacteric;

Consultant Gynaecologist, Queen Charlotte's \& Chelsea Hospital and Chelsea \& Westminster Hospital, London, UK

Honorary Senior Lecturer, Imperial College London, London, UK 